\title{
Analisis Kelayakan Ekonomi \& Finansial pada Masterplan Kawasan Industri perikanan Kota Tarakan
}

\author{
Amiruddin Akbar Fisu ${ }^{1 *}$ \\ 1email: amiruddinakbarfisu07@gmail.com \\ Fakultas Teknik Universitas Andi Djemma
}

\begin{abstract}
Abstrak. Penelitian ini merupakan pengkajian/penilaian kelayakan finansial terhadap rencana kegiatan pengembangan Kawasan industri perikanan dengan tujuan untuk menilai apakah masterplan Kawasan Industri Perikanan Tarakan layak untuk dikembangkan ditinjau dari sisi ekonomi dan bisnis. Metode yang digunakan untuk penilaian kelayakan dilakukan dengan menggunakan ukuran-ukuran BCR (Benefit Cost Ratio), NPV (Net Present Value), dan IRR (Internal Rate of Return). Dari hasil analisis dapat dikatakan bahwa perencanaan kawasan industry layak secara ekonomi maupun secara finansial.
\end{abstract}

Kata kunci: Masterplan kawasan industri, Kelayakan finansial, kelayakan ekonomi

\section{Pendahuluan}

Dalam pengembangan suatu kegiatan pembangunan atau pengembangan infrastruktur, perlu ada pengkajian mendalam dari berbagai sisi baik itu dari aspek fisik (daya dukung lahan, jenis konstruksi dan arsitektural yang akan dikembangkan), aspek tata ruang, aspek lingkungan maupun aspek ekonomi, agar kegiatan tersebut tidak merugi bila akan dikembangkan dan mempunyai dampak positif terhadap lingkungan sekitar (baik itu lingkungan alam, lingkungan sosial maupun lingkungan ekonomi). Semua aspek tersebut merupakan prasyarat yang harus diketahui secara utuh, sebelum memulai pengembangan suatu kegiatan. Pemerintah Kota Tarakan merencanakan pembangunan dan pengembangan Kawasan Industri Perikanan dalam rangka meningkatkan aspek perekonomian dan bisnis. Ada banyak variabel yang mempengaruhi para pengusaha untuk tertarik memanfaatkan suatu sarana atau prasarana (Fisu, 2016), termasuk kawasan industry perikanan ini.

Pengkajian/penilaian kelayakan finansial terhadap rencana kegiatan pengembangan Kawasan industri perikanan dengan tujuan untuk menilai apakah kegiatan tersebut layak untuk dikembangkan ditinjau dari sisi ekonomi dan bisnis. Pada dasarnya dalam mengkaji kelayakan finansial perlu dilihat perbandingan nilai manfaat dan nilai biaya yang dikeluarkan. Untuk melihat itu, prosedur standar penilaian kelayakan dilakukan dengan menggunakan ukuran-ukuran BCR (Benefit Cost Ratio), NPV (Net Present Value), dan IRR (Internal Rate of Return) (Hermawati, 2011).

\section{Landasan Teori}

\section{a. Benefit Cost Ratio (BCR)}

Metode BCR secara ringkas membandingkan besarnya perbandingan keuntungan terhadap biaya yang dikeluarkan selama umur rencana, dalam hal ini selama 20 tahun. Indikator dari nilai BCR dapat dijelaskan sebagai berikut:

$\mathrm{BCR}>1$ menunjukkan bahwa proyek akan menguntungkan,

$\mathrm{BCR}<1$ menunjukkan bahwa prtoyek tersbeut tidak layak atau merugi,

$\mathrm{BCR}=1$ menunjukkan rasio nilai proyek terhadap keuntungan sama besar.

Perhitungan biaya dan keuntungan dilakukan dnegan memberikan faktor diskon sesuai dengan tingkat bunga yang berlaku, dan jangka waktu rencana pembangunan. (Khuzaifah, Saleh, dan Anggraini, 2017)

$$
\mathrm{BCR}=\frac{\text { Present Value Beneffit }}{\text { Capital Cost }}
$$




\section{b. $\quad$ Net Present value (NPV)}

Penalaran metoda ini sederhana. Jumlah cash in flows dikonversikan ke nilai saat ini (present Value) dengan tingkat suku bunga yang dikenakan. Bila jumlah cash in flows dengan nilai saat ini sama dengan biaya investasi atau dengan kata lain NPV=0, maka pendapatan hanya cukup untuk membayar biaya investasi. Proyek disebut layak atau dapat diterima bila NPV lebih dari 0. (Khuzaifah, Saleh, dan Anggraini, 2017)

$$
\mathrm{NPV}=\sum_{\mathrm{t}=0}^{\mathrm{n}} \frac{\mathrm{Bt}-\mathrm{Ct}}{(1+\mathrm{r})^{\mathrm{t}}}
$$

\section{c. Internal Rate of Return (IRR)}

IRR dipergunakan untuk mengetahui tingkat bunga yang mengakibatkan NPV sama dengan nol. Dengan mengetahui tingkat bunga saat ini dan juga kecenderungannya di masa mendatang maka dapat diambil keputusan untuk mengimplementasikan suatu kegiatan. Besarnya IRR harus lebih besar dari tingkat bunga yang digunakan saat ini. Apabila IRR lebih rendah maka akan dapat dikatan bahwa proyek tidak layak. Dalam hal Pembangunan (Khuzaifah, Saleh, dan Anggraini, 2017).

Kawasan Industri Perikanan Terpadu Kota Tarakan, investasi direncanakan beberapa kali cash outflow menyebaban proyek ini mempunyai cash flows yang disebut non-normal. Kondisi ini menimbulkan kemungkinan lebih dari satu hasil IRR (multiple IRR). Karenanya guna meninjau kelayakan proyek dari segi rate of return, modified IRR (MIRR) lebih sesuai untuk diaplikasikan. MIRR dapat dirumuskan sebagai berikut.

$$
\mathrm{EIRR}=i_{1}+\left(i_{2}-i_{1}\right) \frac{N P V_{1}}{N P V_{2}-N P V_{1}}
$$

\section{Research Methods}

Jenis penelitian yang digunakan adalah penelitian deskriptif dengan pendekatan kuantitatif. Perhitungan kelayakan, baik secara ekonomi maupun finansial, dilakukan dengan menerapkan beberapa metode diantaranya yaitu: Metode Benefit Cost Ratio (BCR), Metode Net Present Value (NPV) dan Metode Internal Rate of Return (IRR). Pelaksanaan metode penelitian deskriptif tidak terbatas sampai pada pengumpulan dan penyusunan data, tetapi meliputi analisis dan interpretasi tentang data tersebut. (Fisu, 2016)

Prosedur penelitian yang dilakukan untuk mengestimasi kelayakan finansial, adalah dengan mengestimasi biaya pembangunan atau investasi dari masterplan Kawasan Industri Perikanan Kota Tarakan, lalu mengestimasi biaya opersaional berdasarkan standar, regulasi atau peraturan dan penelitian-pnelitian sebelumnya. Setelah itu juga dilakukan estimasi pendapatan dari infrastruktur yang ada. Ketika ketiga komponen estimasi ini diperoleh, maka akan dihitung cash flownya.

Untuk estimasi kelayakan ekonomi, digunakan data PDRB kota tarakan dan mengestimasi peroyeksi PDRB dengan scenario Kawasan Industri Perikanan dibangun maupun tidak dibangun. Selisih dari dua scenario PDRB tersebut yang kemudian akan dihitung cash flownya dengan metode Benefit Cost Ratio (BCR), Metode Net Present Value (NPV) dan Metode Internal Rate of Return (IRR).

\section{Result and discussion}

\section{a. Analisis Finansial}

\section{Analisis Biaya}

Biaya yang dikenakan pada kawasan industri sudah diatur dalam peraturan pemerintah RI 
Nomor 15 Tahun 2016 tentang Tarif atas Jenis Penerimaan Bukan Pajak yang berlaku. Oleh karenanya kawasan industri tidak dapat menentukan sendiri tarif yang akan diberlakukan dalam hal sewa tanah, sewa ruangan (konsesi), pemasangan reklame.

Dalam rangka penyesuaian terhadap inflasi, maka diasumsiakan tarif-tarif tersebut akan mengalami peningkatan. Inflasi pada tahun-tahun mendatang.

\section{Prakiraan Investasi}

Investasi yang akan ditinjau disini adalah investasi yang akan dilaksanakan. Untuk pembangunan tahap I dan pengembangan tahap II. Biaya investasi tersebut digunakan untuk penyiapan lahan, pembangunan infrastruktur jalan, pelabuhan, kantor, bangunan operasional, dan lain-lain berdasarkan masterplan Kawasan Industri Perikanan Tarakan.

Tabel 1 Prakiraan Total Biaya Investasi

\begin{tabular}{cr}
\hline Tahap & Biaya Investasi \\
\hline I & $33,127,620,000.00$ \\
\hline II & $70,782,570,000.00$ \\
\hline Total & $103,910,190,000.00$ \\
\hline
\end{tabular}

\section{Prakiraan Pendapatan}

Arus kas Kawasan Industri Perikanan Tarakan tediri dari pemasukan atau penerimaan (reveneu) dan pengeluaran (expenditure). Penerimaan Kawasan Industri Perikanan Tarakan diperoleh sebagai berikut.

Sewa Lahan. Sesuai Peraturan Daerah Kota Tarakan Nomor 02 Tahun 2012, tariff penggunaan lahan/tanah milik pemerintah oleh pihak swasta adalah Rp. 750,00 per hari $/ \mathrm{m}^{2}$, diasumsikan pada tahun operasi akan meningkat menjadi Rp.1.000,00 per hari $/ \mathrm{m}^{2}$ dan mengalami kenaikan $7.5 \%$ tiap tahunnya.

Retribusi kebersihan. Perhitungan pendapatan dari retribusi ini mengacu pada Peraturan Peraturan Daerah Kota Tarakan No 02 Tahun 2015 Tentang Perubahan atas Peraturan daerah Kota Tarakan Nomor 01 Tahun 2012 Tentang Retribusi jasa Umum, dimana retribusi pelayananpersampahan/ kebersihan untuk industry menengah adalah sebesar Rp.200.000,00 per bulan. Diasumsikan bahwa jumlah industry pada tahap I sebanyak 11 unit industry (seluas 10,5 ha) dan pada tahap II meningkat menjadi 35 unit industry (seluas $35 \mathrm{ha}$ ).

Jasa tambat dan labuh. Sesuai dengan Peraturan Pemerintah Nomor 75 Tahun 2015, jasa tambat dan labuh pada pelabuhan perikanan untuk kapal >15GT hingga 20GT sebesar Rp.2.500,00- per kapal per etmal dan diasumsikan membutuhkan durasi waktu sekitar 2 jam setiap armada kapal untuk pendaratan ikan. Tarif ini diasumsikan akan mengalami peningkatan $7,5 \%$ per tahun..

Jasa pengadaan es. Pendapatan dari Pelayanan Jasa pengadaan es juga mengacu pada Peraturan Pemerintah Nomor 75 Tahun 2015, yaitu Rp. 150,00 per kg dan diasumsikan naik $7.5 \%$ per tahunnya. Kebutuhan es diasumsikan rata-rata adalah $220 \mathrm{~kg}$ es tiap 1 ton ikan.

Jasa pengadaan air bersih. Pendapatan dari jasa pelayanan air bersih mengacu pada Peraturan Pemerintah Nomor 75 Tahun 2015 tentang jenis dan Tarif atas Penerimaan Negara Bukan Pajak yang Berlaku Pada Kementerian Kelautan dan Perikanan, yaitu memperoleh Rp.60,00,- tiap liter dari pemakaian air bersih untuk keperluan industry perikanan dan diasumsikan naik 7,5\% tiap tahunnya. Kebutuhan air bersih mengacu pada patokan rata-rata kebutuhan air bersih industry pengolahan di PP yaitu 1,5 liter per $1 \mathrm{~kg}$ bahan baku ikan.

Jasa sewa bangunan. Jumlah bangunan yang disewakan pada tahap I direncanakan sebanyak 11 unit pada 5 tahun pertama, 16 unit pada 5 tahun kedua, bartambah menjadi 23 unit pada 5 tahun pertama di tahap II dan 30 unit pada 5 tahun kedua di tahap II. Biaya sewa bangunan adalah Rp.10.000.000 per unit per tahun dan mengalami kenaikan 7,5\% tiap tahunnya.

Jasa penyediaan listrik. Kebutuhan listrik kawasan industry mengacu pada Peraturan Menteri perindustrian Nomor 35/M-IND/Per/2010 tentang Pedoman Teknis Kawasan 
Industri, dimana kebutuhan listrik sebesar 0,15 - 0,2 MVA/Ha. Keuntungan atau benefit dari jasa ini mengacu pada Peraturan Pemerintah Nomor 75 Tahun 2015 tentang jenis dan Tarif atas Penerimaan Negara Bukan Pajak yang Berlaku Pada Kementerian Kelautan dan Perikanan, dimana terdapat penambahan biaya $10 \%$ yang menjadi benefit dari tiap Kwh listrik yang dibayarkan ke PLN. Hasil perkiraan pendapatan dapat dilihat pada table 2.

\section{Analisis Prakiraan Pengeluaran}

Sumber-sumber pengeluaran (cost center) Kawasan Industri Perikanan Tarakan terbentuk dari akumulasi belanja pegawai, biaya operasi, biaya pemeliharaan (light repair), biaya operasional (air dan listrik) serta biaya lainnya.

Dasar estimasi biaya operasional dan biaya non-operasional ini mengacu pada Peraturan Pemerintah Nomor 75 Tahun 2015 tentang jenis dan Tarif atas Penerimaan Negara Bukan Pajak yang Berlaku Pada Kementerian Kelautan dan Perikanan. Biaya operasional diperkirakan meningkat sebesar $5 \%$ per tahun.

Gaji Pegawai. mencakup gaji/upah, tunjangan dan biaya diklat. Pengamatan memperlihatkan bahwa biaya ini proporsional dengan besarnya bangunan operasional non komersil pada kawasan industri, dan jumlah pegawai mengacu pada Peraturan Menteri perindustrian Nomor 35/M-IND/Per/2010 tentang Pedoman Teknis Kawasan Industri yaitu 90 - 110 tenaga $\mathrm{kerja} / \mathrm{Ha}$.

Biaya Pemeliharaan (maintenance). mencakup pemeliharaan semua aset termasuk lahan, dermaga, bangunan, dan peralatan, termasuk kebersihan. Biaya ini proporsional dengan nilai aset, diperkirakan pada awalnya besarnya $0,5 \%$ dari nilai aset dan meningkat $2,5 \%$ tiap tahunnya.

Biaya operasional. berupa rekening listrik dan air. Biaya ini mengacu pada Peraturan Menteri perindustrian Nomor 35/M-IND/Per/2010 tentang Pedoman Teknis Kawasan Industri, dimana kebutuhan listrik sebesar $0,15-0,2 \mathrm{MVA} / \mathrm{Ha}$ dan air $0,55-0,75 \mathrm{liter} / \mathrm{detik} /$ Ha. Tarif listrik pada tahun operasi diasumsikan sebesar Rp. $12.550 \mathrm{Kwh}$ dan air Rp.12.500,00- per $\mathrm{m}^{3}$, atau Rp. 12,50,00- per liter. Kelompok biaya ini diasumsikan meningkat dengan laju $5 \%$ per tahun.

Biaya lainnya. Biaya lainnya merupakan komponen biaya, baik biaya operasional maupun non operasional di luar komponen yang telah di jelaskan sebelumnya, dan disumsikan sebesar $3 \%$ dari total cost yang dikeluarkan.

Perkiraan pengeluaran Kawasan Industri perikanan Kota Tarakan dapat dilihat pada table 3

Analisis finansial dilakukan dengan menghitung nilai NPV, BC Ratio dan FIRR. Perhitungan ini dilakukan dengan menggunakan tingkat bunga atau tingkat diskon sebesar 11,50\%. Tabel nilai present value tiap-tiap tahun dan hasil analisis finansial disajikan sebagai dalam tabel 4 . 
Tabel 2 Proyeksi Pendapatan Kawasan Industri Perikanan Tarakan

\begin{tabular}{|c|c|c|c|c|c|c|c|c|}
\hline Tahun & Sewa Lahan & $\begin{array}{c}\text { Retribusi } \\
\text { Kebersihan }\end{array}$ & $\begin{array}{c}\text { Jasa Tambat \& } \\
\text { Labuh }\end{array}$ & Pengadaan Es & Air Bersih & Sewa Bangunan & Listrik & Jumlah \\
\hline 2019 & 105.000 .000 & 26.400 .000 & - & - & 11.669 .107 & 110.000 .000 & 1.143 .219 .420 & 1.396 .288 .527 \\
\hline 2020 & 112.875 .000 & 28.380 .000 & - & - & 14.049 .605 & 118.250 .000 & 1.228 .960 .877 & 1.502 .515 .481 \\
\hline 2021 & 121.340 .625 & 30.508 .500 & - & - & 16.915 .724 & 127.118 .750 & 1.321 .132 .942 & 1.617 .016 .541 \\
\hline 2022 & 130.441 .172 & 32.796 .638 & - & - & 14.744 .123 & 136.652 .656 & 1.420 .217 .913 & 1.734 .852 .501 \\
\hline 2023 & 140.224 .260 & 35.256 .385 & - & - & 24.521 .304 & 213.675 .063 & 1.526 .734 .256 & 1.940 .411 .268 \\
\hline 2024 & 150.741 .079 & 37.900 .614 & - & - & 29.523 .651 & 229.700 .692 & 1.641 .239 .326 & 2.089 .105 .362 \\
\hline 2025 & 162.046 .660 & 40.743 .160 & - & - & 35.546 .475 & 246.928 .244 & 1.764 .332 .275 & 2.249 .596 .815 \\
\hline 2026 & 174.200 .160 & 43.798 .897 & - & - & 42.797 .956 & 265.447 .862 & 1.896 .657 .196 & 2.422 .902 .071 \\
\hline 2027 & 187.265 .172 & 47.083 .815 & - & - & 51.528 .739 & 285.356 .452 & 2.038 .906 .485 & 2.610 .140 .663 \\
\hline 2028 & 201.310 .060 & 50.615 .101 & - & - & 62.040 .602 & 440.964 .892 & 2.191 .824 .472 & 2.946 .755 .127 \\
\hline 2029 & 721.361 .047 & 173.126 .651 & - & - & 74.696 .885 & 474.037 .259 & 7.854 .037 .690 & 9.297 .259 .533 \\
\hline 2030 & 775.463 .125 & 186.111 .150 & 682.459 .316 & 4.984.253.430 & 89.935 .050 & 509.590 .054 & 8.443 .090 .517 & 15.670 .902 .641 \\
\hline 2031 & 833.622 .860 & 200.069 .486 & 821.681 .016 & 6.001 .041 .129 & 108.281 .800 & 547.809 .308 & 9.076 .322 .306 & 17.588 .827 .905 \\
\hline 2032 & 896.144 .574 & 215.074 .698 & 989.303 .943 & 7.225 .253 .520 & 130.371 .287 & 588.895 .006 & 9.757 .046 .479 & 19.802 .089 .507 \\
\hline 2033 & 963.355 .417 & 231.205 .300 & 1.191 .121 .948 & 8.699.205.238 & 156.967 .029 & 633.062 .131 & 10.488 .824 .965 & 22.363 .742 .028 \\
\hline 2034 & 1.035.607.073 & 248.545 .698 & 1.434 .110 .825 & 10.473 .843 .106 & 188.988 .303 & 680.541 .791 & 11.275 .486 .837 & 25.337 .123 .634 \\
\hline 2035 & 1.113 .277 .604 & 267.186 .625 & 1.726 .669 .434 & 12.610 .507 .100 & 227.541 .917 & 731.582 .425 & 12.121 .148 .350 & 28.797.913.455 \\
\hline 2036 & 1.196 .773 .424 & 287.225 .622 & 2.078 .909 .998 & 15.183 .050 .548 & 273.960 .468 & 786.451 .107 & 13.030 .234 .476 & 32.836 .605 .644 \\
\hline 2037 & 1.286 .531 .431 & 308.767 .543 & 2.503 .007 .638 & 18.280 .392 .860 & 329.848 .404 & 845.434 .940 & 14.007 .502 .062 & 37.561 .484 .878 \\
\hline 2038 & 1.383 .021 .288 & 331.925 .109 & 3.013 .621 .196 & 22.009 .593 .004 & 397.137 .478 & 1.185 .446 .819 & 15.058 .064 .716 & 43.378 .809 .610 \\
\hline 2039 & 1.486 .747 .885 & 356.819 .492 & 3.628 .399 .920 & 26.499 .549 .976 & 478.153 .524 & 1.274 .355 .330 & 16.187 .419 .570 & 49.911 .445 .698 \\
\hline 2040 & 1.598 .253 .976 & 383.580 .954 & 4.368 .593 .503 & 31.905 .458 .171 & 575.696 .843 & 1.369 .931 .980 & 17.401 .476 .038 & 57.602 .991 .466 \\
\hline 2041 & 1.718 .123 .025 & 412.349 .526 & 5.259 .786 .578 & 38.414 .171 .638 & 693.138 .998 & 1.472 .676 .878 & 18.706 .586 .741 & 66.676 .833 .385 \\
\hline 2042 & 1.846 .982 .252 & 443.275 .740 & 6.332 .783 .040 & 46.250 .662 .653 & 834.539 .354 & 1.583 .127 .644 & 20.109 .580 .746 & 77.400 .951 .429 \\
\hline
\end{tabular}


Tabel 3 Perkiraan Pengeluaran Kawasan Industri Perikanan Tarakan

\begin{tabular}{|c|c|c|c|c|c|c|}
\hline Tahun & Maintenance & Air Bersih & Listrik & Gaji karyawan & Lainnya & Total \\
\hline 2019 & 500.000 .000 & 20.672 .834 & 207.630 .422 & 86.750 .000 & 20.376 .331 & 835.429 .587 \\
\hline 2020 & 502.500 .000 & 22.223 .296 & 223.202 .704 & 86.750 .000 & 20.866 .900 & 855.542 .900 \\
\hline 2021 & 505.012 .500 & 23.890 .043 & 239.942 .907 & 86.750 .000 & 21.389 .886 & 876.985 .336 \\
\hline 2022 & 507.537 .563 & 25.681 .796 & 257.938 .625 & 86.750 .000 & 21.947 .700 & 899.855 .683 \\
\hline 2023 & 510.075 .250 & 27.607 .931 & 277.284 .022 & 86.750 .000 & 22.542 .930 & 924.260 .133 \\
\hline 2024 & 512.625 .627 & 29.678 .526 & 298.080 .323 & 91.087 .500 & 23.286 .799 & 954.758 .775 \\
\hline 2025 & 515.188 .755 & 31.904 .415 & 320.436 .347 & 91.087 .500 & 23.965 .425 & 982.582 .443 \\
\hline 2026 & 517.764 .698 & 34.297 .247 & 344.469 .074 & 91.087 .500 & 24.690 .463 & 1.012 .308 .982 \\
\hline 2027 & 520.353 .522 & 36.869 .540 & 370.304 .254 & 91.087 .500 & 25.465 .370 & 1.044 .080 .187 \\
\hline 2028 & 522.955 .290 & 39.634 .756 & 398.077 .073 & 91.087 .500 & 26.293 .865 & 1.078 .048 .484 \\
\hline 2029 & 1.522 .955 .290 & 80.768 .545 & 588.960 .607 & 175.848 .750 & 59.213 .330 & 2.427 .746 .521 \\
\hline 2030 & 1.530 .570 .066 & 86.826 .186 & 633.132 .653 & 175.848 .750 & 60.659 .441 & 2.487 .037 .096 \\
\hline 2031 & 1.538 .222 .916 & 93.338 .150 & 680.617 .602 & 175.848 .750 & 62.200 .685 & 2.550 .228 .103 \\
\hline 2032 & 1.545 .914 .031 & 100.338 .511 & 731.663 .922 & 175.848 .750 & 63.844 .130 & 2.617 .609 .344 \\
\hline 2033 & 1.553 .643 .601 & 107.863 .899 & 786.538 .716 & 175.848 .750 & 65.597 .374 & 2.689 .492 .340 \\
\hline 2034 & 1.561 .411 .819 & 115.953 .691 & 845.529 .120 & 184.641 .188 & 67.688 .395 & 2.775 .224 .213 \\
\hline 2035 & 1.569 .218 .878 & 124.650 .218 & 908.943 .804 & 184.641 .188 & 69.686 .352 & 2.857 .140 .440 \\
\hline 2036 & 1.577 .064 .973 & 133.998 .985 & 977.114 .589 & 184.641 .188 & 71.820 .493 & 2.944 .640 .227 \\
\hline 2037 & 1.584 .950 .297 & 144.048 .909 & 1.050 .398 .183 & 184.641 .188 & 74.100 .964 & 3.038 .139 .541 \\
\hline 2038 & 1.592 .875 .049 & 154.852 .577 & 1.129 .178 .047 & 184.641 .188 & 76.538 .671 & 3.138 .085 .531 \\
\hline 2039 & 1.600 .839 .424 & 166.466 .520 & 1.213 .866 .400 & 193.873 .247 & 79.376 .140 & 3.254 .421 .731 \\
\hline 2040 & 1.608 .843 .621 & 178.951 .509 & 1.304 .906 .380 & 193.873 .247 & 82.164 .369 & 3.368 .739 .126 \\
\hline 2041 & 1.616 .887 .839 & 192.372 .872 & 1.402 .774 .359 & 193.873 .247 & 85.147 .708 & 3.491 .056 .025 \\
\hline 2042 & 1.624 .972 .279 & 206.800 .837 & 1.507 .982 .436 & 193.873 .247 & 88.340 .720 & 3.621 .969 .519 \\
\hline
\end{tabular}


Tabel 4 Cash Flow Analisis Finansial Kawasan Industri Kota Tarakan

\begin{tabular}{|c|c|c|c|c|c|c|c|c|}
\hline Tahun & Tahun Ke- & Investasi & Cost & Benefit & Net flow & Discount rate & NPV & Cumulative flow \\
\hline 2018 & 0 & 33.127 .620 .000 & 0 & 0 & -33.127 .620 .000 & 1,00000 & -33.127 .620 .000 & -33.127 .620 .000 \\
\hline 2019 & 1 & & 835.429 .587 & 1.396 .288 .527 & 560.858 .940 & 0,89686 & 503.012 .502 & -32.624 .607 .498 \\
\hline 2020 & 2 & & 855.542 .900 & 1.502 .515 .481 & 646.972 .581 & 0,80436 & 520.398 .626 & -32.104 .208 .872 \\
\hline 2021 & 3 & & 876.985 .336 & 1.617 .016 .541 & 740.031 .205 & 0,72140 & 533.857 .602 & -31.570 .351 .271 \\
\hline 2022 & 4 & & 899.855 .683 & 1.734 .852 .501 & 834.996 .818 & 0,64699 & 540.238 .276 & -31.030 .112 .995 \\
\hline 2023 & 5 & & 924.260 .133 & 1.940 .411 .268 & 1.016 .151 .135 & 0,58026 & 589.635 .971 & -30.440 .477 .024 \\
\hline 2024 & 6 & & 954.758 .775 & 2.089 .105 .362 & 1.134 .346 .587 & 0,52042 & 590.332 .324 & -29.850 .144 .699 \\
\hline 2025 & 7 & & 982.582 .443 & 2.249 .596 .815 & 1.267 .014 .372 & 0,46674 & 591.367 .522 & -29.258 .777 .177 \\
\hline 2026 & 8 & & 1.012 .308 .982 & 2.422 .902 .071 & 1.410 .593 .090 & 0,41860 & 590.476 .765 & -28.668 .300 .412 \\
\hline 2027 & 9 & & 1.044 .080 .187 & 2.610 .140 .663 & 1.566 .060 .476 & 0,37543 & 587.942 .321 & -28.080 .358 .091 \\
\hline 2028 & 10 & 70.782 .570 .000 & 1.078 .048 .484 & 2.946 .755 .127 & -68.913 .863 .357 & 0,33671 & -23.203 .736 .425 & -51.284 .094 .516 \\
\hline 2029 & 11 & & 2.427 .746 .521 & 9.297 .259 .533 & 6.869 .513 .011 & 0,30198 & 2.074 .447 .314 & -49.209 .647 .202 \\
\hline 2030 & 12 & & 2.487 .037 .096 & 15.670 .902 .641 & 13.183 .865 .545 & 0,27083 & 3.570 .625 .948 & -45.639 .021 .254 \\
\hline 2032 & 14 & & 2.617 .609 .344 & 19.802.089.507 & 17.184 .480 .163 & 0,21785 & 3.743 .589 .804 & -38.242 .562 .210 \\
\hline 2033 & 15 & & 2.689 .492 .340 & 22.363 .742 .028 & 19.674.249.688 & 0,19538 & 3.843 .927 .324 & -34.398 .634 .886 \\
\hline 2034 & 16 & & 2.775 .224 .213 & 25.337 .123 .634 & 22.561 .899 .421 & 0,17523 & 3.953 .463 .929 & -30.445 .170 .957 \\
\hline 2035 & 17 & & 2.857 .140 .440 & 28.797.913.455 & 25.940 .773 .015 & 0,15715 & 4.076 .713 .280 & -26.368 .457 .678 \\
\hline 2036 & 18 & & 2.944 .640 .227 & 32.836 .605 .644 & 29.891 .965 .417 & 0,14095 & 4.213 .149 .386 & -22.155 .308 .291 \\
\hline 2037 & 19 & & 3.038 .139 .541 & 37.561 .484 .878 & 34.523 .345 .338 & 0,12641 & 4.364 .056 .778 & -17.791 .251 .514 \\
\hline 2038 & 20 & & 3.138 .085 .531 & 43.378 .809 .610 & 40.240 .724 .079 & 0,11337 & 4.562 .138 .219 & -13.229 .113 .294 \\
\hline 2039 & 21 & & 3.254 .421 .731 & 49.911 .445 .698 & 46.657 .023 .967 & 0,10168 & 4.744 .001 .511 & -8.485 .111 .784 \\
\hline 2040 & 22 & & 3.368 .739 .126 & 57.602 .991 .466 & 54.234 .252 .340 & 0,09119 & 4.945 .686 .402 & -3.539 .425 .382 \\
\hline 2041 & 23 & & 3.491.056.025 & 66.676.833.385 & 63.185.777.360 & 0,08179 & 5.167 .701 .064 & 1.628.275.682 \\
\hline \multirow[t]{2}{*}{2042} & 24 & & 3.621 .969 .519 & 77.400 .951 .429 & 73.778 .981 .911 & 0,07335 & 5.411 .726 .511 & 7.040 .002 .193 \\
\hline & & & 50.725 .382 .267 & 524.736 .565 .170 & & & & \\
\hline
\end{tabular}


Dari table 4 di atas, diperoleh hasil analisis finansial yang dapat dilihat pada table 5 di bawah ini:

Tabel 5 Hasil Analisis Kelayakan Finansial

\begin{tabular}{lr}
\hline Kriteria & Hasil \\
\hline Disc. Rate (WACC) & $11,50 \%$ \\
\hline NPV & 6313903312 \\
\hline IRR & 0.13 \\
\hline BCR & 10,34465472 \\
\hline $\begin{array}{l}\text { Payback period } \\
\text { (tahun) }\end{array}$ & 23 \\
\hline Status Investasi & Layak \\
\hline
\end{tabular}

Berdasarkan table di atas, dapat disimpulkan bahwa Pembangunan Kawasan Industri Perikanan Tarakan adalah layak secara finansial untuk dilakukan. Beberapa indikator menunjukkan hal tersebut. Nilai NPV positif Rp.6.313.903.312 dan nilai IRR 13\% yang lebih besar dari nilai discount rate yaitu 11,5\%. Pada Indikator BCR, dapat dilihat bahwa:

$$
\text { BCR }=\text { PV Benefit } / \text { PVInvestasi }=524,73 / 50,72=10,40
$$

Dengan nilai BCR lebih dari 1 maka pembangunan Kawasan Industri Perikanan Tarakan secara finansial adalah layak.

Pada indikator payback period di estimasikan akan terjadi pada tahun ke 23.

\begin{abstract}
Analisis Kelayakan Ekonomi
Kelayakan ekonomi didefinisikan sebagai kelayakan bagi semmua pihak yang memanfaatkan, baik langsung maupun tidak langsung suatu pembangunan proyek, termasuk pembangunan kawasan Industri Perikanan Tarakan ini. Tujuan analisis ekonomi adalah untuk menetukan apakah implementasi suatu proyek layak atas dasar with or without cases yang menentukan keuntungan ekonomi (net ekonomic benefit) yang akan didapat dengan mengimplementasikan proyek tersebut. Untuk menentukan net economic benefit perlu ditinjau perbedaan produktivitas ekonomis pada kondisi dengan dan tanpa proyek. Proyek dikatakan layak apabila economic productivity mengalami peningkatan. Economic costs and benefits suatu proyek, diukur dalam terminologi moneter, dihitung secara analisa cash flow, sedangkan analisa cost benefit dihitung berdasarkan discount cash flow. Selanjutnya kelayakan ekonomi dalam terminologi ekonomi nasional ditentukan berasarkan Economic Interna Rate of Return (EIRR) dari proyek yang bersangkutan.

Perhitungan manfaat didasarkan pada perbedaan biaya yang harus dikeluarkan oleh pengguna (langsung maupun tidak langsung) pada kondisi tanpa proyek dan dengan proyek. Istilah ini digunakan untuk membedakan dengan konsep before dan after project.
\end{abstract}

\title{
Proyeksi Pertumbuhan Ekonomi
}

Salah satu indikator utama untuk melilhat oertumbuhan perekonoian suatu wilayah adalah pertumbuhan Pendapatan Regional Domestik Bruto (PDRB). PDRB pada dasarnya merupakan penjumlahan dari keseluruhan nilai tambah yang dihasilkan oleh semua aktivitas ekonomi yang berada di suatu daerah. Penyajian data PDRB biasanya disajikan dalam dua cara, yaitu PDRB atas dasar harga yang berlaku.

Untuk dapat menjadi sebuah usaha yang hidup dan dapat bertahan untuk jangka panjang, serta dapat menarik investor untuk menanam modal, suatu unit usaha harus mencapai unjuk kerja finansial yang baik. Oleh karena itu berikut ini akan dikaji kelayakan ekonomi pada pembangunan kawasan industri tersebut. 
Manfaat ekonomi pada suatu daerah dipresentasikan dengan adanya Produk Domestik Regional Bruto (PDRB). Data PDRB Kota Tarakan telah disajikan dalam kajian gambaran umum wilayah. Namun demikian perlu ditunjukan kembali sebagai berikut :

Tabel 6 PDRB Kota Tarakan Atas Dasa Harga Berlaku Menurut Lapangan Usaha Juta Rupiah) Tahun 2013-2016

\begin{tabular}{|c|c|c|c|c|}
\hline Lapangan Usaha & 2013 & 2014 & 2015 & 2016 \\
\hline $\begin{array}{l}\text { Pertanian, Kehutanan, dan } \\
\text { Perikanan }\end{array}$ & $2.126 .485,34$ & $2.445 .017,34$ & $2.706 .944,40$ & $2.823 .088,10$ \\
\hline Pertambangan dan Penggalian & $1.245 .789,40$ & $1.407 .933,00$ & $1.332 .710,90$ & $1.207 .175,60$ \\
\hline Industri Pengolahan & $2.182 .098,41$ & $2.589 .079,71$ & $2.835 .526,30$ & $3.130 .361,30$ \\
\hline Pengadaan Listrik dan Gas & $11.837,34$ & $12.805,51$ & $13.484,40$ & $17.941,00$ \\
\hline $\begin{array}{l}\text { Pengadaan Air, Pengelolaan } \\
\text { Sampah, Limbah dan Daur } \\
\text { Ulang }\end{array}$ & $16.125,43$ & $18.127,88$ & $19.505,30$ & $20.741,60$ \\
\hline Konstruksi & $2.512 .185,13$ & $2.880 .641,61$ & $3.159 .530,90$ & $3.607 .590,20$ \\
\hline $\begin{array}{l}\text { Perdagangan Besar dan Eceran; } \\
\text { Reparasi Mobil dan Sepeda } \\
\text { Motor }\end{array}$ & $3.402 .938,65$ & $3.866 .693,17$ & 4.417.169,90 & $4.998 .488,60$ \\
\hline Transportasi dan Pergudangan & $2.066 .194,96$ & $2.460 .919,32$ & $2.933 .570,20$ & $3.367 .039,90$ \\
\hline $\begin{array}{l}\text { Penyediaan Akomodasi dan } \\
\text { Makan Minum }\end{array}$ & $343.042,58$ & $421.017,22$ & $470.292,20$ & $533.289,70$ \\
\hline Informasi dan Komunikasi & $596.378,91$ & $712.339,75$ & $792.107,70$ & $884.661,70$ \\
\hline Jasa Keuangan dan Asuransi & $451.564,30$ & $506.773,60$ & $549.959,30$ & $619.774,20$ \\
\hline $\begin{array}{l}\text { Real Estat/Real Estate } \\
\text { Activities }\end{array}$ & $213.950,86$ & $242.578,92$ & $264.591,20$ & $280.128,00$ \\
\hline Jasa Perusahaan & $115.064,83$ & $131.474,74$ & $136.073,50$ & $141.399,50$ \\
\hline $\begin{array}{l}\text { Administrasi Pemerintahan, } \\
\text { Pertahanan dan Jaminan Sosial } \\
\text { Wajib }\end{array}$ & $759.222,12$ & $893.891,07$ & $933.672,50$ & $1.068 .959,30$ \\
\hline Jasa Pendidikan & $433.813,78$ & $531.311,49$ & $599.046,80$ & $706.863,20$ \\
\hline $\begin{array}{l}\text { Jasa Kesehatan dan Kegiatan } \\
\text { Sosial }\end{array}$ & $254.222,28$ & $310.468,50$ & $393.255,60$ & $487.498,50$ \\
\hline Jasa Lainnya & $107.131,48$ & $141.827,20$ & $182.219,20$ & $226.850,60$ \\
\hline PDRB & $16.838 .045,80$ & $19.572 .900,03$ & $21.739 .660,30$ & $24.121 .851,00$ \\
\hline
\end{tabular}

Dari tabel tersebut terdapat pertumbuhan yang besarnya diprediksi dengan metode statistik faktor pertumbuhan dari masing-masing lapang usaha. Prediksi pertumbuhan ini diperkirakan kawasan industri perikanan tidak dikembangkan. Selang waktu proyeksi adalah 2018 sampai dengan 2042. Hasil proyeksi dapat dilihat pada tabel Prakiraan PDRB tanpa pembangunan kawasan industri perikanan kotaTarakan. Dalam kelayakan ekonomi dengan beroperasinya kawasan industri perikanan tersebut diasumsikan fasilitas ini menjadi penggerak dari sektor ekonomi kabupaten, terjadi multiplier efek terhadap sektor-sektor lapang usaha. Sektor-sektor lapangan usaha yang berpengaruh dan mengalami pertumbuhan adalah sektor perikanan, listrik, air bersih dan persampahan, konstruksi, industri, perdagangan, transportasi dan pergudangan, dan jasa perusahaan.

Sektor pertanian, industri, listrik dan air bersih, bangunan, perdagangan hotel dan restoran, perdagangan, angkutan, keuangan dan jasa mengalami peningkatan sekitar $0,15 \%-0,4 \%$ pada waktu Kawasan Industri Perikanan Tarakan beroperasi.

Manfaat ekonomi dari pembangunan Kawasan Industri Perikanan adalah selisih dari PDRB setelah Kawasan Industri Perikanan dikembangkan dengan Kawasan Industri Perikanan sebelum dikembangkan yang disajikan dalam Tabel 7 Manfaat Ekonomi Pembangunan Kawasan Industri Perikanan Tarakan. 
Tabel 7 Manfaat Ekonomi Dengan Pembangunan Kawasan Industri Perikanan Tarakan (juta rupiah)

\begin{tabular}{|c|c|c|c|}
\hline Tahun & $\begin{array}{c}\text { Proyeksi PDRB Tanpa } \\
\text { Pembangunan Kawasan Industri } \\
\text { Perikanan }\end{array}$ & $\begin{array}{c}\text { Proyeksi PDRB dengan } \\
\text { Pembangunan Kawasan Industri } \\
\text { Perikanan }\end{array}$ & Manfaat \\
\hline 2018 & $30,974,900.70$ & $30,974,900.70$ & 0 \\
\hline 2019 & $35,173,445.05$ & $35,235,723.70$ & $62,278.65$ \\
\hline 2020 & $39,995,450.08$ & $40,066,078.73$ & $70,628.65$ \\
\hline 2021 & $45,539,828.82$ & $45,619,956.60$ & $80,127.78$ \\
\hline 2022 & $51,922,418.19$ & $52,013,356.52$ & $90,938.33$ \\
\hline 2023 & $59,279,126.59$ & $59,382,372.73$ & $103,246.13$ \\
\hline 2024 & $67,769,718.69$ & $67,886,982.71$ & $117,264.03$ \\
\hline 2025 & $77,582,376.74$ & $77,715,612.63$ & $133,235.90$ \\
\hline 2026 & $88,939,210.53$ & $89,090,651.87$ & $151,441.34$ \\
\hline 2027 & $102,102,928.49$ & $102,275,129.50$ & $172,201.00$ \\
\hline 2028 & $117,384,933.07$ & $117,580,815.85$ & $195,882.78$ \\
\hline 2029 & $135,155,166.90$ & $135,378,075.84$ & $222,908.95$ \\
\hline 2030 & $155,854,115.12$ & $156,107,879.54$ & $253,764.41$ \\
\hline 2031 & $180,007,468.59$ & $180,296,474.81$ & $289,006.23$ \\
\hline 2032 & $208,244,076.52$ & $208,573,351.14$ & $329,274.61$ \\
\hline 2033 & $241,317,973.74$ & $241,693,279.41$ & $375,305.68$ \\
\hline 2034 & $280,135,463.04$ & $280,563,409.19$ & $427,946.14$ \\
\hline 2035 & $325,788,480.72$ & $326,276,651.10$ & $488,170.39$ \\
\hline 2036 & $379,595,783.33$ & $380,152,883.47$ & $557,100.14$ \\
\hline 2037 & $443,153,886.26$ & $443,789,913.63$ & $636,027.37$ \\
\hline 2038 & $518,400,178.64$ & $519,126,619.32$ & $726,440.69$ \\
\hline 2039 & $607,691,263.89$ & $608,521,319.92$ & $830,056.03$ \\
\hline 2040 & $713,900,364.49$ & $714,849,216.73$ & $948,852.24$ \\
\hline 2041 & $840,538,627.88$ & $841,623,740.13$ & $1,085,112.25$ \\
\hline 2042 & $991,906,434.67$ & $993,147,905.59$ & $1,241,470.93$ \\
\hline
\end{tabular}

Selain meningkatnya PDRB Kota Tarakan, terdapat juga manfaat ekonomi lainnya, seperti terbukanya lapangan kerja baru, bertambahnya aktifitas di sekitar kawasan industri perikanan, hingga munculnya atau meningkatnya tingkat ekonomi masyarakat di sekitar Kawasan industri perikanan ketika beroperasi. Analisis indikator kelayakan ekonomi disajikan dalam tabel Indikator Kelayakan Ekonomi berikut. Tingkat suku bunga atau discounted rate yang digunakan adalah $15 \%$. 
Tabel 8 Indikator Kelayakan Ekonomi Kawasan Industri Perikanan Kota Tarakan

\begin{tabular}{|c|c|c|c|c|c|c|c|c|}
\hline Tahun & Manfaat & PV Manfaat & Investasi & PV Investasi & Net Flow & PV Manfaat Kumulatif & PV Investasi Kumulatif & NPV \\
\hline 2018 & - & - & 33.127 .620 .000 & 28.806 .626 .087 & -28.806 .626 .087 & 0 & 33.127 .620 .000 & -33.127 .620 .000 \\
\hline 2019 & 6.227 .865 .136 & - & & - & 0 & - & - & 0 \\
\hline 2020 & 7.062 .864 .987 & 4.643 .948 .376 & & - & 4.643 .948 .376 & 4.643 .948 .376 & - & 4.643.948.376 \\
\hline 2021 & 8.012 .777 .781 & 4.581 .331 .702 & & - & 4.581 .331 .702 & 9.225 .280 .079 & - & 9.225 .280 .079 \\
\hline 2022 & 9.093 .833 .272 & 4.521 .242 .338 & & - & 4.521 .242 .338 & 13.746 .522 .416 & - & 13.746 .522 .416 \\
\hline 2023 & 10.324 .613 .499 & 4.463 .615 .333 & & - & 4.463 .615 .333 & 18.210.137.749 & - & 18.210 .137 .749 \\
\hline 2024 & 11.726 .402 .549 & 4.408 .389 .063 & & - & 4.408 .389 .063 & 22.618 .526 .812 & - & 22.618 .526 .812 \\
\hline 2025 & 13.323 .589 .649 & 4.355 .505 .090 & & - & 4.355 .505 .090 & 26.974.031.902 & - & 26.974 .031 .902 \\
\hline 2026 & 15.144 .133 .888 & 4.304 .908 .027 & & - & 4.304 .908 .027 & 31.278 .939 .930 & - & 31.278 .939 .930 \\
\hline 2027 & 17.220 .100 .227 & 4.256 .545 .414 & & - & 4.256 .545 .414 & 35.535 .485 .344 & - & 35.535 .485 .344 \\
\hline 2028 & 19.588 .277 .988 & 4.210 .367 .598 & 70.782 .570 .000 & 15.214 .233 .708 & -11.003 .866 .110 & 39.745 .852 .942 & 70.782 .570 .000 & -31.036 .717 .058 \\
\hline 2029 & 22.290 .894 .802 & 4.166 .327 .622 & & - & 4.166.327.622 & 43.912 .180 .564 & - & 43.912 .180 .564 \\
\hline 2030 & 25.376 .441 .083 & 4.124 .381 .117 & & - & 4.124.381.117 & 48.036 .561 .682 & - & 48.036 .561 .682 \\
\hline 2031 & 28.900 .622 .551 & 4.084 .486 .200 & & - & 4.084.486.200 & 52.121 .047 .882 & - & 52.121 .047 .882 \\
\hline 2032 & 32.927 .461 .095 & 4.046 .603 .380 & & - & 4.046 .603 .380 & 56.167 .651 .262 & - & 56.167 .651 .262 \\
\hline 2033 & 37.530 .567 .633 & 4.010 .695 .468 & & - & 4.010 .695 .468 & 60.178 .346 .730 & - & 60.178 .346 .730 \\
\hline 2034 & 42.794 .614 .395 & 3.976 .727 .490 & & - & 3.976 .727 .490 & 64.155 .074 .220 & - & 64.155 .074 .220 \\
\hline 2035 & 48.817 .038 .569 & 3.944 .666 .606 & & - & 3.944 .666 .606 & 68.099 .740 .826 & - & 68.099 .740 .826 \\
\hline 2036 & 55.710 .014 .427 & 3.914 .482 .034 & & - & 3.914 .482 .034 & 72.014 .222 .861 & - & 72.014 .222 .861 \\
\hline 2037 & 63.602 .737 .136 & 3.886 .144 .980 & & - & 3.886 .144 .980 & 75.900 .367 .841 & - & 75.900 .367 .841 \\
\hline 2038 & 72.644 .068 .528 & 3.859 .628 .566 & & - & 3.859 .628 .566 & 79.759.996.407 & - & 79.759.996.407 \\
\hline 2039 & 83.005 .603 .369 & 3.834 .907 .765 & & - & 3.834 .907 .765 & 83.594 .904 .172 & - & 83.594 .904 .172 \\
\hline 2040 & 94.885 .224 .277 & 3.811 .959 .346 & & - & 3.811 .959 .346 & 87.406 .863 .518 & - & 87.406 .863 .518 \\
\hline 2041 & 108.511 .224 .723 & 3.790 .761 .810 & & - & 3.790 .761 .810 & 91.197 .625 .329 & - & 91.197 .625 .329 \\
\hline 2042 & 124.147.092.615 & 3.771 .295 .340 & & - & 3.771.295.340 & 94.968 .920 .669 & - & 94.968 .920 .669 \\
\hline
\end{tabular}


Perhitungan kelayakan ekonomi dilakukan berdasarkan tingkat discounted rate $15 \%$, menunjukan PV investasi/Biaya sebesar 44 milyar dan PV manfaat (benefit) sebesar 94 milyar seperti yang diperlihatkan pada tabel di atas. Berdasarkan ini maka Benefit Cos Ratio (BCR) adalah :

\section{BCR = PV Benefit/PVInvestasi $=94,97 / 44,02=2,15$}

Dengan nilai BCR lebih dari 1 maka dapat dikatakan pembangunan Kawasan Industri Perikanan Tarakan secara ekonomi adalah layak.Indikator kelayakan ekonomi yang telah disampaikan dalam kelayakan ekonomi yang dapat dikuantifikasikan atau dikenal dengan istilah tangible benefit. Meskipun manfaat tersebut tidak terwujud dalam penerimaan uang secara langsung, nilai manfaat tersebut tergolong manfaat ekonomi yang secara langsung diperoleh masyarakat dan pemerintah bila dibandingkan dengan tanpa dibangunnya kawasan industri perikanan.

Manfaat lain yang tidak dapat dihitung secara langsung, yaitu nilai manfaat yang secara tidak langsung diperoleh masyarakat dan pemerintah bila kawasan industri tersebut dikembangkan. Nilai manfaat ini bersifat kuantitatif dan subyektif, seperti peningkatan pertumbuhan ekonomi wilayah, peningkatan produktivitas masyarakat, peningkatan pendapatan pajak akibat peningkatan skala kegiatan ekonomi regional, manfaat pembangunan, nilai kenyamanan, perasaan aman dan lainnya.

Adanya peningkatan PDRB artinya terjadi peningkatan konsumsi, dan peningkatan peningkatan konsumsi berdampak pada peningkatan tabungan, peningkatan tabungan berdampak pada peningkatan investasi, dan seterusnya, sehingga terjadi proses multiplier akan berlanjut. Dari sisi ini menunjukan bahwa adanya pembangunan kawasan industri perikanan yang memiliki sifat strategis dapat memberikan dampak berganda sehingga akan memberikan keuntungan ekonomis bagi pertumbuhan ekonomi wilayah.

\section{Conclusion}

Dari hasil analisis kelayakan finansial, dapat dikatakan, perencanaan Kawasan Industri Perikanan Kota Tarakan pada masterplan layak secara finansial. Hal ini dapat dilihat dari indicator penilaian BCR, NPV, dan IRR.

Hal yang sama juga terjadi pada analisis kelayakan ekonomi, dengan menggunakan PDRB sebagai indikatornya, juga dapat dikatakan layak. Dengan demikian, masterplan Kawasan Industri Perikanan Kota Tarakan direkomendasikan untuk direalisasikan.

\section{References}

[1] Fatra Mudjari. (2010). Tingkat Kebutuhan dan Penyediaan Es Untuk Keperluan Operasi Panangkapan Ikan di PPS Cilacap. Departement Pemanfaatan Sumberdaya Perikanan Fakultas Perikanan dan Ilmu Kelautan Institute Pertanian Bogor.

[2] Fisu A.A, (2016); Analisis dan Konsep Perencanaan Kawasan Pelabuhan Kota Penajam Sebagai Pintu Gerbang Kab. Penajam Paser Utara Kalimantan Timur. Jurnal Pena Teknik, Vol 01 No.02 (125-136)

[3] Fisu A.A, (2016); Potensi Demand Pengembangan Kanal Jongaya \& Panampu Sebagai Moda Transportasi Kota Makassar; Jurnal Manajemen Transportasi \& Logistik, Vol.03 No.03 (285-298)

[4] Khuzaifah, Saleh, dan Anggraini Kurnia, (2017); Kelayakan Ekonomi Jalan Batas Kota Tapaktuan - Bakongan Ditinjau dari Segi Konsumers Surplus;Jurnal Teknik Sipil Universitas Syiah Kuala; Vol.01 No.02 (393 - 404)

[5] Peraturan Daerah Kota Tarakan No.2 Tahun 2015 Tentang Perubhan Atas Peraturan Daerah No.1 Tahun 2012 Tentang Retribusi Jasa Umum

[6] Peraturan Menteri Perindustrian Republik Indonesia No.35/M-Ind/Per/3/2010 Tentang Pedoman Teknis Kawasan Industri 
[7] Peraturan Pemerintah Republik Indonesia Nomor 75 Tahun 2015 Tentang Jenis Dan Tarif Atas Jenis Penerimaan Negara Bukan Pajak Yang Berlaku Pada Kementerian Kelautan Dan Perikanan. 